\title{
ASPEK PENGAWASAN CORPORATE GOVERNANCE TERHADAP TINGKAT PENGUNGKAPAN LINGKUNGAN (STUDI KASUS PADA PERUSAHAAN MANUFAKTUR DI BEI PERIODE TAHUN 2014-2018)
}

\author{
Rihan Mustafa Zahri \\ D3 Manajemen Pajak, Fakultas Ekonomi dan Bisnis, Universitas PGRI Madiun, Indonesia
}

\begin{abstract}
This research aims to obtain empirical evidence about the role of corporate governance oversight on environmental disclosure. The independent variables tested in this research consisted of the corporate governance oversight aspects (proportion of BOC independent, ethnic background of president BOC, educational background of president of $B O C$, frequency of meeting $B O C$, proportion of committee audit independent, frequency of meetings audit committee, diversity gender of $B O C)$, while the dependent variable is environmental disclosure measured by using GRI 4.0. The sample of this research consist of 89 manufacture companies listed in stock exchange of Indonesia from 2014-2018. This research is quantitative research which the sampling method is purposive sampling. Data of corporate governance aspects were collected from annual reports and analysis of this research is multiple regression analysis. The result of this research showed that ethnic background of BOC have negative significant, proportion of committee audit independent have positive significant, frequency of meetings audit committee have positive significant on environmental disclosure.
\end{abstract}

Keyword: Corporate Governance Oversight Aspects; Environmental Disclosure; Ethnic Background

\begin{abstract}
Abstrak
Penelitian ini bertujuan untuk memperoleh bukti empiris tentang peran pengawasan tata kelola perusahaan terhadap pengungkapan lingkungan. Variabel independen yang diuji dalam penelitian ini terdiri dari aspek pengawasan tata kelola perusahaan (proporsi Dewan Komisaris independen, latar belakang etnis presiden Dewan Komisaris, latar belakang pendidikan presiden Dewan Komisaris, frekuensi rapat Dewan Komisaris, proporsi komite audit independen, frekuensi rapat komite audit, diversitas gender Dewan Komisaris), sedangkan variabel dependennya adalah pengungkapan lingkungan yang diukur dengan menggunakan GRI 4.0. Sampel penelitian ini terdiri dari 89 perusahaan manufaktur yang terdaftar di Bursa Efek Indonesia tahun 2014-2018. Penelitian ini merupakan penelitian kuantitatif dengan metode pengambilan sampel adalah purposive sampling. Data aspek corporate governance dikumpulkan dari laporan tahunan dan analisis penelitian ini adalah analisis regresi berganda. Hasil penelitian menunjukkan bahwa latar belakang etnis Dewan Komisaris berpengaruh signifikan negatif, proporsi komite audit independen signifikan, frekuensi rapat komite audit berpengaruh positif signifikan terhadap pengungkapan lingkungan.
\end{abstract}

Kata kunci: Aspek Pengawasan Tata Kelola Perusahaan; Pengungkapan Lingkungan, Latar Belakang Ras

Article History: Received: (15-09-2020); Revised: (05-10-2020); and Published: (31-10-2020)

Copyright (C) 2020 Rihan Mustafa Zahri

How to cite this article: Zahri, R. M (2020). Aspek Pengawasan Corporate Governance Terhadap Tingkat Pengungkapan Lingkungan (Studi Kasus Pada Perusahaan Manufaktur di BEI Periode Tahun 2014-2018). Managament Insight: Jurnal Ilmiah Manajemen. 15(2), 242-259

Retrevied from: https://ejournal.unib.ac.id/index.php/Insight 


\section{PENDAHULUAN}

Pada dasarnya perusahaan berperan sebagai penyedia barang dan jasa yang diperlukan oleh masyarakat, akan tetapi aktifitas perusahaan terkadang mempunyai dampak negatif kepada masyarakat (Almilia dan Wijayanto, 2007). Seringnya dampak negatif yang ditimbulkan oleh aktifitas perusahaan, maka akhir-akhir tahun ini Indonesia mengalami peningkatan permasalahan pencemaran lingkungan hidup (Suratno, Darsono, dan Mutmainah, 2006). Hal ini diakibatkan banyaknya perusahaan yang belum melakukan pengungkapan aktifitas lingkungan hidup (Anggraini dan Reni, 2006).

Permasalahan pencemaran lingkungan masih sering terjadi di Indonesia, WALHI (2017) menyatakan bahwa sekitar 30 pabrik yang berada di kawasan Dayeuhkolot, Kabupaten Bandung, membuang limbah sembarangan ke aliran sungai Citepus yang mengakibatkan bau tidak sedap dan kondisi air yang mengakibatkan gatal-gatal di sekitar pemukiman warga. Sementara itu, terdapat kasus lingkungan hidup baik nasional maupun daerah yang teradvokasi oleh WALHI pada tahun 2017 meliputi 13 provinsi (WALHI, 2018). Hal ini menunjukkan bahwa kondisi lingkungan hidup di Indonesia semakin memburuk setiap tahunnya karena praktik korporasi dan Negara yang hanya memperhatikan dampak ekonomi dan pembangunan nasional tanpa memikirkan dampak lingkungannya.

Padahal sebelumya pemerintah di tahun 2012 mengeluarkan regulasi tentang Peraturan Pemerintah Republik Indonesia Nomor 47 tahun 2012 Tentang Tanggung Jawab Sosial dan Lingkungan Perseroan Terbatas dan poin penting terdapat pada pasal 2 dan pasal 3 ayat 1 . Faktanya, regulasi ini hanya sebatas pernyataan yang tidak ditindak lanjuti dengan serius oleh pemerintah dan tidak memberikan solusi terhadap dampak lingkungan yang terjadi selama ini. Karena hal tersebut, Indonesia menjadi negara berkembang yang masih sangat rendah tingkat environmental disclosure dibanding negara lain (Sufian \& Zahan, 2013). Indonesia masih berada diperingkat 11 negara asia pasifik dimana tingkat implementasi GCG (good corporate governance) yang sangat lemah ditinjau dari CG Watch Market Score (Lukviarman, 2016).

Maka dari itu, corporate governance menjadi elemen penting untuk meningkatkan transparansi, akuntabilitas, serta mengukur kesehatan perusahaan (Rokhimatika dan Afandy, 2017; Suhardjanto, 2010). Lebih lanjut, Suhardjanto (2010) menyatakan bahwa karena di dalam perusahaan yang mempunyai good corporate governance salah satunya didukung dengan adanya aspek pengawasan yang dipegang oleh dewan komisaris. Hal ini sesuai kondisi struktur organisasi perusahaan Indonesia yang memakai Two Board System bahwa dewan komisaris berfungsi mengawasi kinerja dewan direksi (KNKG, 2011).

Dalam menjalankan fungsi pengawasan dewan komisaris dibantu dengan dewan komisaris independen sebagai pihak yang tidak terafiliasi dengan perusahaan terkait (KNKG, 2006). Dalam keefektivan pengawasan perusahaan juga didukung 
dengan karakteristik presiden dewan komisaris dimana pemikiran seorang dewan dipengaruhi latar belakang etnis, pendidikan dan diversitas gender (Carter, Simkins \& Simpson, 2003). Hal tersebut akan meminimalisir kecurangan yang dilakukan direksi, meningkatkan nilai perusahaan di mata stakeholders dan meningkatkan efektivitas pengawasan kinerja (Chtourou, Bedard, Courteu, 2001 \& Said, Zainuddin, Haron, 2010).

Aspek pengawasan yang mendukung dalam good corporate governance lainnya adalah komite audit (Suhardjanto, 2010). Komite audit berfungsi membantu dewan komisaris dalam meningkatkan transparansi dan akuntabilitas perusahaan dengan anggota komite audit yang independen (Bapepam, 2004). Dengan demikian aspek pengawasan corporate governance akan meningkatkan tanggung jawab lingkungan dan mengurangi asymetry information perusahaan (Sulistyowati, 2014).

Beberapa penelitian terdahulu terkait "aspek pengawasan corporate governance terhadap environmental disclosure" yaitu; Akbas (2016), Suhardjanto (2010), Khan, Muttakin \& Siddiqui (2013), Fortunella \& Hadiprajitno (2015), Lie, Pike, \& Haniffa (2008), Kharis \& Suhardjanto (2012), Liao, Luo \& Tang (2014), setyawan \& kamila (2015), Supatminingsih \& Wicaksono (2016). Dari penelitian sebelumnya menunjukkan hasil yang tidak konsisten terhadap tingkat environmental disclosure.

Studi ini bertujuan menguji kembali variabel yang tidak konsisten pada aspek pengawasan corporate governance terhadap tingkat environmental disclosure dan menambahkan variabel diversitas gender dewan komisaris agar dapat mengetahui kemampuan kinerja dari dewan komisaris pria maupun wanita dan menggunakan data yang lebih baru, yaitu dari annual report perusahaan manufaktur tahun 2014-2018.

\section{TINJAUAN PUSTAKA}

\section{Teori Agensi}

Widjaja dan Maghviroh (2011) menjelaskan bahwa teori keagenan menjelaskan tentang pola hubungan dua pihak yang memiliki kepentingan yang berbeda, yaitu principal (pemegang saham) dan agent (manajer). Hubungan antara keduanya disebut juga (the principal agent relationship) akan terjadi dalam organisasi perusahaan antara pemegang saham (stockholders) sebagai principal dengan pengelola (managers) sebagai agent dalam hubungan tersebut (Lukviarman, 2016). Lebih lanjut Lukviarman (2016) mengatakan bahwa kedua pihak ini memiliki kepentingan masing-masing (self interests) dan kepentingan tersebut lebih banyak mengalami perbedaan dari sudut pandang keduanya (divergence of interests).

Keinginan yang berbeda tersebut membuat principal membutuhkan mekanisme untuk senantiasa memonitor agent, namun mekanisme kontrol tersebut sulit dilakukan dan menimbulkan biaya mahal (Lukviarman, 2016). Lebih lanjut Lukviarman (2016) menyatakan bahwa ketidakseimbangan informasi akan memicu munculnya 
kondisi asymmetry information dimana agent mempunyai kesempatan untuk melakukan manajemen laba mengenai kondisi ekonomi perusahaan.

\section{Teori Stakeholder}

Teori stakeholder adalah sebuah teori manajerial tentang bisnis (Freeman, 2001). Hal ini menegaskan apakah bisnis dapat dipahami sebagai serangkaian hubungan anatar kelompok yang memiliki kepentingan dalam kegiatan bisnis tersebut (Visser, 2008). Konsep stakeholder adalah generalisasi gagasan pemegang saham, dimana mereka mempunyai beberapa klaim khusus terhadap perusahaan (Freeman, 2001). Disisi lain Crowther dan Aras (2008) mengatakan bahwa ada dua cara utama untuk mengklasifikasikan pemangku kepentingan :

1) Internal dan Eksternal

Internal stakeholder termasuk dalam organisasi, seperti karyawan atau manajer. Sebaliknya eksternal stakeholder adalah kelompok seperti pemasok atau pelanggan yang umumnya tidak dianggap sebagai bagian dari organisasi.

2) Voluntary dan Involuntary

Voluntary stakeholder dapat memilih apakah akan menjadi pemangku kepentingan atau tidak untuk suatu organisasi, seperti karyawan sedangkan involuntary tidak bisa, seperti masyarakat setempat.

\section{Teori Legitimasi}

Teori legitimasi menyiratkan bahwa pengungkapan lingkungan adalah fungsi dari intensitas tekanan masyarakat dan politik yang dihadapi oleh perusahaan mengenai kinerja lingkungan (Cho \& Patten, 2007). Dalam hal ini reaksi perusahaan mencoba memberikan informasi lingkungan yang lebih banyak agar terhindar dari tuntutan masyarakat (Pratama et al, 2014). Burgwal \& Viera (2014) menyatakan bahwa organisasi yang baik adalah berusaha untuk menyeimbangkan nilai-nilai organisasi dan nilai-nilai sosial, apabila usaha itu tercapai akan ada kontrak sosial anatara keduanya. Jika masyarakat mengamati bahwa organisasi tersebut gagal beroperasi atau gagal mencapai kesepakatan dengan kontrak sosial, nilai sosial tidak sesuai dengan nilai organisasi, maka akan ada opini masyarakat yang negatif mengenai organisasi ini (Milne \& Patten, 2002). Pendapat negatif semacam itu merupakan ancaman bagi kelangsungan organisasi yang sering disebut dengan legitimacy gap dan dapat menghancurkan legitimasi organisasi yang berujung pada berakhirnya eksistensi perusahaan (Ghozali \& Chariri, 2007).

\section{Teori Signaling}

Teori signal merupakan sinyal-sinyal informasi yang dibutuhkan oleh investor untuk mempertimbangkan dan menentukan apakah para investor akan menanamkan 
sahamnya atau tidak pada perusahaan yang bersangkutan (Suwardjono, 2010). Lebih lanjut suwardjono (2010) menyatakan bahwa sinyal ini bisa berupa informasi dalam (inside information) berupa kebijakan dalam perusahaan yang tidak tersedia secara publik, tetapi akhirnya akan terefleksi dalam angka laba yang dipublikasikan melalui laporan keuangan.

\section{Corporate Governance}

Definisi corporate governance secara komprehensif merupakan sistem yang mengatur dan mengendalikan perusahaan untuk meningkatkan keberhasilan dan akuntabilitas perusahaan dalam mewujudkan nilai tambah perusahaan dengan memperhatikan kepentingan stakeholders (Monks dan minow, 2003). Di Indonesia model struktur corporate govenance menggunakan two board system dimana dewan pengurus perusahaan terdiri Direksi yang bertindak sebagai dewan eksekutif dan Komisaris bertindak sebagai dewan pengawas perusahaan (KNKG, 2006). Disebutkan dalam UU No. 40 Tahun 2007 bahwa Direksi bertanggungjawab penuh atas pengelolaan perusahaan, sedangkan Komisaris bertanggungjawab memberikan pengawas secara khusus dan memberikan nasihat kepada Direksi. Bila sistem ini berjalan dengan baik akan terwujudnya hubungan yang harmonis antara Direksi, Komisaris, Pemengang Saham, dan Stakeholders serta dapat mencapai tujuan perusahaan yaitu bertambahnya nilai perusahaan (Lukviarman, 2016).

\section{Environmental Disclosure}

Environmental Disclosure adalah pengungkapan informasi yang berkaitan dengan lingkungan hidup di dalam laporan tahunan perusahaan yang meliputi pengendalian terhadap polusi, pencegahan atau perbaikan terhadap kerusakaan lingkungan, dan konservasi alam (Zhegal dan Ahmed, 1990 dan Suratno et al, 2006). Melalui environmental disclosure para stakeholders dapat mengetahui aktivitasaktivitas dan mengevaluasi kinerja perusahaan terkait lingkungan hidup melalui annual reports maupun website perusahaan (Brown dan Deegan, 1998). Selain itu, Miranti, (2009) menjelaskan bahwa dengan adanya environmental disclosure diharapkan terhindar dari tuntutan masyarakat, memperoleh kepercayaan dari para stakeholders, dan menjadi perusahaan yang berkelanjutan.

\section{PENGEMBANGAN HIPOTESIS}

\section{Proporsi Dewan Komisaris Independen dan Tingkat Environmental Disclosure}

Keberadaan dewan komisaris independen mempunyai pengawasan yang baik terhadap direksi guna mengurangi kemungkinan kecurangan dalam pelaporan keuangan maupun environmental disclosure (Cho, C.H. dan Pattern, 2007). Dari penjelasan di atas, maka dikembangkan hipotesis sebagai berikut: 
$\mathbf{H}_{\mathbf{1}}$ : Proporsi dewan komisaris independen berpengaruh positif signifikan terhadap tingkat environmental disclosure.

\section{Latar Belakang Etnis Presiden Komisaris dan Tingkat Environmental Disclosure}

Penelitian ini ingin meneliti latar belakang etnis manakah yang bisa mempengaruhi tingkat environmental disclosure. Pandangan orang tentang etnis tionghoa adalah memiliki etos kerja yang tinggi, hemat, disiplin dan berorientasi pada kesukesesan material semata dibanding orang pribumi (Sugiyono, 2007). Dengan adanya filosofi etos kerja yang dimiliki etnis tionghoa dapat meningkatkan kinerja presiden komisaris, sehingga bisa meningkatkan environmental disclosure perusahaan (Setyawan, 2005). Dari penjelasan di atas, maka dikembangkan hipotesis sebagai berikut:

$\mathbf{H}_{\mathbf{2}}$ : Latar belakang etnis presiden komisaris berpengaruh positif signifikan terhadap tingkat environmental disclosure.

\section{Latar Belakang Pendidikan Presiden Komisaris dan Tingkat Environmental Disclosure}

Penelitian ini ingin meneliti latar belakang pendidikan manakah yang bisa mempengaruhi tingkat environmental disclosure. Secara teori bahwa presiden dewan komisaris yang memiliki latar belakang pendidikan ekonomi atau bisnis akan memiliki pengetahuan bisnis untuk mengelola perusahaan dengan baik dan lebih menaati aturan pemerintah terkait environmental disclosure (Kharis dan Suhardjanto, 2012). Dari penjelasan di atas, maka dikembangkan hipotesis sebagai berikut:

$\mathbf{H}_{3}$ : Latar belakang pendidikan presiden komisaris berpengaruh positif signifikan terhadap tingkat environmental disclosure.

\section{Jumlah Rapat Dewan Komisaris dan Tingkat Environmental Disclosure}

Secara teori semakin tinggi frekuensi rapat anatara anggota dewan akan semakin baik pula komunikasi untuk mencapai sebuah GCG termasuk diantaranya pengungkapan environmental disclosure (Suryono \& Prastiwi, 2011). Dari penjelasan di atas, maka dikembangkan hipotesis sebagai berikut:

$\mathbf{H}_{\mathbf{4}}$ : Jumlah rapat dewan komisaris berpengaruh signifikan terhadap tingkat environmental disclosure.

\section{Proporsi Komite Audit Independen dan Tingkat Environmental Disclosure}

Komite audit independen tidak terafiliasi dengan perusahaan atau komite lainnya, sehingga kinerjanya dapat dipercaya, bisa meningkatkan kualitas kontrol perusahaan dan meningkatkan kualitas environmental disclosure (Mc Mullen, 1996 dan Forker, 1992). Dari penjelasan di atas, maka dikembangkan hipotesis sebagai berikut:

$\mathbf{H}_{5}$ : Proporsi komite audit independen berpengaruh positif signifikan terhadap tingkat environmental disclosure. 


\section{Jumlah Rapat Komite Audit dan Tingkat Environmental Disclosure}

Berdasarkan OJK No.55/POJK.04/2015 bahwa komite audit mengadakan rapat secara berkala paling sedikit 1 (satu) kali dalam 3 (tiga) bulan. Semakin seringnya rapat komite audit akan meningkatkan fungsi pengawasan secara efektif dan meninngkatkan environmental disclosure perusahaan (Corporate Governance Guidelines, 2007). Dari penjelasan di atas, maka dikembangkan hipotesis sebagai berikut:

$\mathbf{H}_{6}$ : Jumlah rapat komite audit berpengaruh positif signifikan terhadap tingkat environmental disclosure.

\section{Diversitas Gender Dewan Komisaris dan Tingkat Environmental Disclosure}

Diversitas gender dewan komisaris telah menjadi ornamen penting dalam tata kelola perusahaan yang mempengaruhi tingkat environmental disclosure perusahaan (Liao, Luo dan Tang, 2014). Diversitas gender yang semakin banyak akan memberikan perspektif atau pemikiran yang lebih beragam sehingga menghasilkan inovasi, kreatifitas dan meminimalisir konflik perusahaan sehingga akan meningkatkan kinerja dewan dalam melakukan environmental disclosure perusahaan (Carter et al., 2003 dan Luckerath, 2011). Dari penjelasan di atas, maka dikembangkan hipotesis sebagai berikut:

$\mathbf{H}_{\mathbf{7}}$ : Diversitas gender berpengaruh positif signifikan terhadap tingkat environmental disclosure.

Berdasarkan pengembangan hipotesis diatas, maka model penelitian ini digambarkan dengan gambar berikut : 




Gambar 1. Kerangka Konseptual

\section{Pengukuran Variabel Independen}

\section{Proporsi Dewan Komisaris Independen}

Indikator yang digunakan dalam variabel ini mengadopsi penelitian dari suhardjanto (2010), Khan (2010), Khan et al. (2013), dan Akbas (2016) yaitu persentase anggota dewan komisaris yang berasal dari luar perusahaan dari seluruh ukuran anggota dewan komisaris perusahaan. Indikator inilah yang sering dipakai peniliti untuk mengukur proporsi dewan komisaris independen, maka peneliti menggunakan rumus seperti dibawah ini :

$$
\text { Proporsi Komisaris Independen }=\frac{\sum \text { Komisaris Independen }}{\sum \text { Anggota Dewan Komisaris }}
$$

\section{Latar Belakang Etnis Presiden Komisaris}

Latar belakng etnis presiden komisaris dalam penelitian ini diukur menggunakan variabel dummy. Indikator variabel ini mengadopsi dari penelitian yang telah dilakukan oleh kusumastuti, Supatmi, \& Sastra (2007) \& Suhardjanto (2010) yaitu untuk presiden komisaris yang berasal dari pribumi dikode 1 , etnis tionghoa dikode 2 , dan berasal dari Negara lain dikode 3 . 


\section{Latar Belakang Pendidikan Presiden Komisaris}

Indikator yang digunakan untuk latar belakang pendidikan presiden komisaris mengadopsi penelitian dari Haniffa \& Cooke (2005), Effendi dkk. (2013) \& Setyawan dkk. (2015) yaitu yang mempunyai latar belakang pendidikan keuangan atau bisnis dikode 1 , sedangkan yang lainnya dikode 0 .

\section{Jumlah Rapat Dewan Komisaris}

Pengukuran jumlah rapat dewan komisaris dalam penelitian ini mengadopsi penelitian dari (Suhardjanto, 2010; Brick \& Chidambaran, 2007; Allegrini \& Greco, 2011) yaitu jumlah rapat yang dilakukan oleh dewan komisaris dalam waktu satu tahun.

$$
\text { Jumlah Rapat }=\sum \text { Rapat Dewan Komisaris }
$$

\section{Proporsi Komite Audit Independen}

Indikator yang digunakan dalam peneiilitian ini mengadopsi dari penelitian Forker (1992), Ho, Simon \& Wong (2001), \& Akbas (2016) yaitu presentase anggota komite audit yang berasal dari luar perusahaan dari seluruh ukuran komite audit perusahaan.

$$
\text { Proporsi Komite Audit Independen } \frac{\sum \text { komite Audit luar perusahaan }}{\sum \text { Komite Audit Perusahaan }}
$$

\section{Jumlah Rapat Komite Audit}

Indikator yang digunakan adalah jumlah rapat komite audit yang diselenggarakan dalam jangka satu tahun, dan susai dengan audit comitte charter (2005), Suhardjanto dan Permatasari (2010) dan Corporate Governance Guidelines (2007).

\section{Jumlah Rapat $=\sum$ Rapat Komite Audit}

\section{Diversitas Gender Komisaris}

Dalam penelitian ini pengukuran diversitas gender komisaris sebagaimana dilakukan oleh Sudiartana (2013) \& Akbas (2016) yaitu jumlah wanita dalam dewan komisaris dibandingkan jumlah seluruh anggota komisaris.

$$
\text { Diversitas Gender }=\frac{\sum \text { Komisaris Perempuan }}{\sum \text { Total Komisaris }}
$$

\section{Pengukuran Variabel Dependen} Environmental Disclosure

Teknik pengukuran menggunakan pedoman GRI 4, ada 46 item aspek lingkungan. Masing-masing isu lingkungan yang diungkapkan diberi skor 1 dan yang 
tidak mendapat nilai 0 atau disebut disclosure scoring (Al Tuwaijiri, Christensen \& Hughes, 2004).

$$
\mathrm{ED}=\frac{\sum \text { item yang diungkapkan }}{\sum \text { pengungkapan lingkungan GRI }}
$$

Variabel environmental disclosure menggunakan indikator GRI karena beberapa negara sering menggunakan GRI untuk pedoman pengungkapan tanggung jawab sosial dan lingkungan (Isaksson \& Steimle, 2009). Pengguna GRI sekitar 1000 organisasi dari 60 negara yang telah memakai kerangka pelaporan GRI (Visser, 2008).

\section{METODE PENELITIAN}

Populasi dan Sampel

Penelitian ini adalah kuantitatif. Pemilihan sampel menggunakan purposive sampling, dimana sampel dipilih berdasarkan kriteria tertentu sebanyak 445 laporan keuangan perusahaan manufaktur yang terdaftar di BEI periode 2014-2018. Analisis data menggunakan metode regeresi berganda dengan menggunakan alat analisis eviews 8.

Alasan peneliti mimilih perusahaan manufaktur karena perusahaan manufaktur mendominasi di dalam BEI dan mendominasi kegiatan industri yang sering berhadapan dengan kerusakan lingkungan (Kartadjumena, Hadi, \& Budiana, 2011). Penggunaan data pada tahun 2014, karena adanya gejolak politik pemilihan presiden yang baru akan menimbulkan kebijakan baru sehingga investor cenderung menunggu daripada membeli atau menjual sahamnya pada saat itu.

Tabel 1. Hasil Pemilihan Sampel

\begin{tabular}{cc}
\hline \hline Keterangan & Jumlah \\
\hline \hline $\begin{array}{c}\text { Perusahaan manufaktur yang terdaftar di BEI } \\
\text { selama periode 2014-2018 }\end{array}$ & $\mathbf{5 6 5}$ \\
$\begin{array}{c}\text { Perusahaan manufaktur yang tidak menerbitkan } \\
\text { annual report }\end{array}$ & $\mathbf{( 1 1 5 )}$ \\
$\begin{array}{c}\text { Perusahaan manufaktur yang tidak } \\
\text { menyediakan informasi environmental } \\
\text { disclosure }\end{array}$ & $\mathbf{( 5 )}$ \\
\hline \hline Jumlah Observasi sebagai sampel & $\mathbf{4 4 5}$ \\
\hline \hline
\end{tabular}

Sumber : Hasil pengolahan data sekunder 2018 


\section{HASIL PENELITIAN STATISTIK DISKRIPTIF}

Tabel 2. Statistik Deskriptif

\begin{tabular}{ccccccc}
\hline \hline & Mean & Median & Maximum & Minimum & Std. Dev & Observations \\
\hline EV & 6.640449 & 4.000000 & 38.00000 & 1.000000 & 6.428833 & 445 \\
PKI & 0.404607 & 0.380000 & 0.800000 & 0.170000 & 0.106898 & 445 \\
ETNIS & 1.806742 & 2.000000 & 3.000000 & 1.000000 & 0.734264 & 445 \\
PEND & 0.375281 & 0.000000 & 1.000000 & 0.000000 & 0.484740 & 445 \\
RK & 6.166292 & 5.000000 & 42.00000 & 1.000000 & 4.870322 & 445 \\
KAI & 0.575326 & 0.670000 & 1.000000 & 0.200000 & 0.156939 & 445 \\
RKA & 6.719101 & 5.000000 & 36.00000 & 1.000000 & 4.970156 & 445 \\
DG & 0.096787 & 0.000000 & 0.670000 & 0.000000 & 0.161007 & 445 \\
\hline \hline
\end{tabular}

Sumber : Hasil pengolahan data 2018

Pada tabel 2 diatas menunjukkan bahwa jumlah sampel keseluruhan 445 buah. Hasil pengujian statistik deskriptif dalam penelitian ini dapat dilihat secara keseluruhan perusahaan manufaktur yang terdaftar di BEI mempunyai indeks environmental disclosure yang berbeda-beda. Dijelaskan bahwa variabel dependen EV memiliki nilai minimum sebesar 1,000, mempunyai nilai Maximum 38,000 dan nilai mean sebesar 6,640 dengan nilai standar deviasi sebesar 6,429. Berdasarkan data tersebut, standar deviasi lebih besar dari nilai mean, sehingga dapat disimpulkan bahwa ada kesenjangan yang cukup besar dari indeks environmental disclosure perusahaan manufaktur yang terdaftar di BEI periode tahun 2014-2018.

Variabel independen PKI dalam penelitian ini memiliki nilai minimum sebesar 0,170 , mempunyai nilai maximum 0,800 dan nilai mean sebesar 0,405 dengan nilai standar deviasi sebesar 0,107. Berdasarkan data tersebut, standar deviasi lebih kecil dari nilai mean, sehingga dapat disimpulkan bahwa tidak ada kesenjangan dari proporsi dewan komisaris independen perusahaan manufaktur yang terdaftar di BEI periode tahun 2014-2018.

Variabel independen ETNIS dalam penelitian ini memiliki nilai minimum sebesar 1,000 , mempunyai nilai maximum 3,000 dan nilai mean sebesar 1,807 dengan nilai standar deviasi sebesar 0,734. Berdasarkan data tersebut, standar deviasi lebih kecil dari nilai mean, sehingga dapat disimpulkan bahwa tidak ada kesenjangan dari latar belakang etnis presiden komisaris perusahaan manufaktur yang terdaftar di BEI periode tahun 2014-2018.

Variabel independen PEND dalam penelitian ini memiliki nilai minimum sebesar 0,000 , mempunyai nilai maximum 1,000 dan nilai mean sebesar 0,375 dengan nilai standar deviasi sebesar 0,485. Berdasarkan data tersebut, standar deviasi lebih besar dari nilai mean, sehingga dapat disimpulkan bahwa ada kesenjangan yang cukup besar dari latar belakang pendidikan presiden komisaris perusahaan manufaktur yang terdaftar di BEl periode tahun 2014-2018. 
Variabel independen RK dalam penelitian ini memiliki nilai minimum sebesar 1,000, mempunyai nilai maximum 42,000 dan nilai mean sebesar 6,166 dengan nilai standar deviasi sebesar 4,870. Berdasarkan data tersebut, standar deviasi lebih kecil dari nilai mean, sehingga dapat disimpulkan bahwa tidak ada kesenjangan dari jumlah rapat dewan komisaris perusahaan manufaktur yang terdaftar di BEI periode tahun 2014-2018.

Variabel independen KAI dalam penelitian ini memiliki nilai minimum sebesar 0,200 , mempunyai nilai maximum 1,000 dan nilai mean sebesar 0,575 dengan nilai standar deviasi sebesar 0,157. Berdasarkan data tersebut, standar deviasi lebih kecil dari nilai mean, sehingga dapat disimpulkan bahwa tidak ada kesenjangan dari proporsi komite audit independen perusahaan manufaktur yang terdaftar di BEI periode tahun 2014-2018.

Variabel independen RKA dalam penelitian ini memiliki nilai minimum sebesar 1,000, mempunyai nilai maximum 36,000 dan nilai mean sebesar 6,719 dengan nilai standar deviasi sebesar 4,970. Berdasarkan data tersebut, standar deviasi lebih kecil dari nilai mean, sehingga dapat disimpulkan bahwa tidak ada kesenjangan dari jumlah rapat komite audit perusahaan manufaktur yang terdaftar di BEI periode tahun 20142018.

Variabel independen DG dalam penelitian ini memiliki nilai minimum sebesar 0,000 , mempunyai nilai maximum 0,670 dan nilai mean sebesar 0,097 dengan nilai standar deviasi sebesar 0,161. Berdasarkan data tersebut, standar deviasi lebih besar dari nilai mean, sehingga dapat disimpulkan bahwa ada kesenjangan yang cukup besar dari diversitas gender dewan komisaris perusahaan manufaktur yang terdaftar di BEI periode tahun 2014-2018.

\section{UJI REGRESI}

Tabel 3. Hasil Uji Regresi Data Panel

\begin{tabular}{ccccc}
\hline Variabel & Coefficient & Std. Error & t-Statistic & Prob. \\
\hline \hline PKI & 1.230097 & 2.568813 & 0.478858 & 0.6323 \\
ETNIS* & -1.142716 & 0.377321 & -3.028498 & 0.0026 \\
PEND & 0.444133 & 0.580058 & 0.765671 & 0.4443 \\
RK & -0.051345 & 0.056738 & -0.904954 & 0.3660 \\
KAI* & 4.642455 & 1.824085 & 2.545086 & 0.0113 \\
RKA* & 0.111730 & 0.055518 & 2.012492 & 0.0448 \\
DG & -3.186909 & 1.720937 & -1.851846 & 0.0647 \\
\hline \hline \multicolumn{5}{c}{ Effects Specification } \\
\hline \hline
\end{tabular}


Berdasarkan hasil regresi diatas menunjukkan bahwa variabel proporsi dewan komisaris independen (PKI; 0,633), latar belakang pendidikan (PEND; 0,445), jumlah rapat dewan komisaris (RK; 0,366), diversitas gender (DG; 0,065) tidak berpangaruh signifikan terhadap tingkat environmental disclosure karena nilai $p$ value $>0,05$. Sementara itu variabel proporsi komite audit $(K A I ; 0,01)$ dan jumlah rapat komite audit (RKA; 0,04) berpengaruh signifikan positif sedangkan variabel latar belakang etnis (ETNIS; 0,02) dengan nilai koefisien -1,143 menunjukkan bahwa berpengaruh signifikan negatif terhadap tingkat environmental disclosure.

\section{PEMBAHASAN}

Hipotesis 1 adalah proporsi komisaris independen tidak berpengearuh signifikan terhadap tingkat environmental disclosure. Hasil ini sejalan dengan penelitian dari Akbas (2016) dan Supatminingsih dkk. (2016). Hasil ini mungkin dikarenakan dewan komisaris independen tidak mempunyai hubungan secara langsung dengan aktivitas atau operasi harian perusahaan sehingga mempengaruhi lemahnya corporate governance perusahaan yang mengakibatkan environmental disclosure tidak tercapai (Effendi dkk., 2012) dan diindikasikan karena pengangkatan komisaris yang kurang efektif dan tidak terbuka, sehingga mengakibatkan dewan komisaris diragukan independensinya yang mengakibatkan lemahnya fungsi pengawasan dan berdampak pada kurangnya tingkat environmental disclosure perusahaan (Fortunella dkk., 2012).

Hipotesis 2 adalah latar belakang etnis presiden komisaris berpengaruh negatif signifikan terhadap tingkat environmental disclosure. Hasil ini sejalan dengan penelitian Katmon, Mohamad, Norwani \& Al farooque (2017) dan bertolak belakang dengan penelitian (Suhardjanto, 2010 \& Setyawan dkk., 2015). Hal ini diindikasikan bahwa etnis pribumi lebih memperhatikan dan peduli terhadap lingkungan sosial perusahaan meraka, dari pada etnis tionghoa yang selalu mengutamakan profitabilitas saja demi kelangsungan perusahaan tanpa memikirkan dampak lingkungan dan sosial.

Hipotesis 3 adalah latar belakang pendidikan presiden komisaris tidak berpengaruh signifikan terhadap tingkat environmental disclosure. Hasil ini sejalan dengan penelitian (Setyawan dkk., 2015). besar atau kecilnya tingkat environmental disclosure perusahaan tidak tergantung pada presiden komisaris yang berlatar belakang ekonomi atau bisnis tetapi kesadaran manajamen dan jajaran dalam menaati aturan (Rahmawati \& Subardjo, 2017). Bagaimanapun manajemen lebih mengetahui informasi tentang operasi perusahaan dari pada dewan komisaris yang tidak secara langsung terjun dalam kegiatan operasi perusahaan (Lukviarman, 2016).

Hipotesis 4 adalah jumlah rapat dewan komisaris tidak berpengaruh signifikan terhadap tingkat environmental disclosure. hasil ini sejalan dengan penelitian (Suhardjanto, 2010). Hal ini diindikasikan bahwa seringnya intensitas rapat dewan komisaris tidak efektif karena akan memakan waktu, pikiran dan biaya sehingga akan 
mengesampingkan kepentingan perusahaan dalam pengungkapan informasi fundamental yang berujung pada kerugian perusahaan (Muntoro, 2005; Bone dan Saputra, 2019).

Hipotesis 5 adalah proporsi komite audit independen berpengaruh positif signifikan terhadap tingkat environmental disclosure. Hasil penelitian ini konsisten dengan Supatminingsih dkk. (2016). Hal ini diindikasikan prinsip komite audit independen memberikan prinsip kontrol, transparansi dan responsibilitas kepada perusahaan sehingga akan memberikan informasi lebih baik terutama ketrebukaan dan jujur dalam penyajiannya (FCGI, 2008). Dengan prinsip tersebut kinerja komite audit independen akan sangat dipercaya, meningkatkan kualitas kontrol perusahaan dan meningkatkan kualitas environmental disclosure (Mc Mullen, 1996 dan Forker, 1992).

Hipotesis 6 adalah jumlah rapat komite audit berpengaruh positif signifikan terhadap tingkat environmental disclosure. Hasil ini konsisten dengan penelitian (Suhardjanto dan Anggitarani, 2010). Hal ini diindikasiakan bahwa Semakin seringnya rapat komite audit akan meningkatkan fungsi pengawasan secara efektif dan meninngkatkan environmental disclosure perusahaan (Corporate Governance Guidelines, 2007).

Hipotesis 7 adalah diversitas gender dewan komisaris tidak berpengaruh signifikan terhadap tingkat environmental disclosure. hasil ini konsisten dengan penelitian (Akbas, 2016). Hal ini diindikasikan bahwa masih ada diskriminasi perempuan dalam pekerjaannya karena perempuan dianggap tidak kompeten dan lebih rendah posisinya dibandingkan pria dalam dunia bisnis (Hogg \& Vaughan, 2008). Sehingga karir perempuan sebagai pihak minoritas terhambat atau kesulitan untuk meningkatkan kinerja perusahaan dan pengungkapan informasi perusahaan (Santrock, 2006).

\section{KESIMPULAN DAN SARAN}

Proporsi dewan komisaris independen tidak berpengaruh signifikan, latar belakang etnis presiden komisaris berpengaruh negatif signifikan, latar belakang pendidikan presiden komisaris tidak berpengaruh signifikan, jumlah rapat dewan komisaris tidak berpengaruh signifikan, proporsi komite audit independen berpengaruh positif signifikan, jumlah rapat komite audit berpengaruh positif signifikan, Diversitas dewan komisaris tidak berpengaruh signifikan, profitabilitas tidak berpengaruh signifikan, leverage berpengaruh negatif signifikan, ukuran perusahaan berpengaruh positif signifikan terhadap tingkat environmental disclosure.

Keterbatasan penelitian ini menggunakan GRI 4 indeks dalam pengukuran tingkat environmental disclosure, dimana pengukuran ini belum bisa diterapkan secara utuh kepada perusahaan yang berada di Indonesia dan peneliti sulit menentukan latar belakang etnis presiden komisaris dikarenakan tidak adanya informasi yang 
menjelaskan hal tersebut, untuk penelitian selanjutnya diharapkan menggunakan IER indeks untuk mengukur tingkat environmental disclosure dikarena sudah di modifikasi oleh Suhardjanto, Tower dan Brown (2008) sehingga sesuai dengan kondisi pengelolaan lingkungan perusahaan di Indonesia dan mencari sumber data tidak hanya lewat annual report saja tetapi lewat website juga agar lebih akurat.

\section{DAFTAR PUSTAKA}

Akbas, H. E. (2014). Company characteristics and environmental disclosure: an empirical investigation on companies listed on borsa istanbul 100 index. The Journal of Accounting And Finance, 29(5-6), 447-471.

Allegrini, M., dan G. Greco. (2011). Corporate boards, audit committees and voluntary disclosure: evidence from italian listed companies. Journal Management Government, 26, 208-209.

Almilia, L. S. dan D. Wijayanto. (2007). Pengaruh environmental performance dan environmental disclousure terhadap economic performance. Proceedings The 1st Accounting Conference (vol. 1).

Al-Tuwaijri, S.A., Christensen, T.E. dan Hughes II, K.E. (2004). The relations among environmental disclosure, environmental performance, and economic performance: a simultaneous equations approach. Accounting, Organizations and Society, 29, 447-471.

Anggraini, Fr. dan Reni, R. (2006). Pengungkapan informasi sosial dan faktor- faktor yang mempengaruhi pengungkapan informasi sosial dalam laporan keuangan tahunan: studi empiris pada perusahaan yang terdaftar di bursa efek jakarta. Simposium Nasional Akuntansi, 9, 1-21.

BAPEPAM. (2004). Badan Pengawas Pasar Modal dan Lembaga Keuangan 2004. Keputusan Ketua Badan Pengawas Pasar Modal No. KEP-29/PM/2004 (Peraturan No IX.I.5) tentang Pembentukan dan Pedoman Pelaksanaan Kerja Komite Audit.

Bone, H., dan Saputra, P. H. (2019). Faktor Individu, Persepsi Risiko, Dan Sikap Terhadap Risiko Dalam Keputusan Berinvestasi Di Pasar Modal. Managament Insight: Jurnal IImiah Manajemen. 14(2), 108-121

Burgwal, D. v. d., dan Vieira, R. J. O. (2014). Environmental disclosure determinants in Dutch listed companies. Revista Contabilidade \& Financas, 25 (64), 60-78.

Brick, E., dan Chidambaran, N.K. (2007). Board Meetings, Committee Structure, and Firm Perfomance. Available at : https://papers.ssrn.com, diakses tanggal 19 juni 2018.

Carter, D.A., Simkins, J. and Simpson, W. G. (2003). Corporate governance, board diversity, and firm value. The Financial Review, 38, 33-53.

Cho. H. C. dan Patten, M. D. (2007). The role of environmental disclosure as tools of legitimacy: a research note. Accounting, Organizations and Society, 32, 7-8. 
Chtourou, S. M., J. B. and Courteau, L. (2001). Corporate governance and earnings management. Working Paper. Universite Laval, Quebec City, Canada.

Corporate Governance Guidelines. (2007). Guidelines on Corporate Governance. Available at : http://phx.corporateir.net/External.File?item=UGFyZW50SUQ9MTQ0NjIwfENoaWxkSUQ9LTF8VHIw ZTOz\&t=1. Diakses tanggal 2 februari 2017

Effendi, B., Uzliawati, L., \& Yulianto, A. S. (2012). Pengaruh dewan komisaris terhadap environmental disclosure pada perusahaan manufaktur yang listing di BEI tahun 2008-2011. Makalah Simposium Nasional Akuntansi XV. Banjarmasin.

FCGI. (2008). Corporate Governance Suatu Pengantar: Peranan Dewan Komisaris dan Komite Audit dalam Pelaksanaan Corporate Governance. Jakarta.

Forker, J.J. (1992). Corporate governance and disclosure quality. Accounting and Business Research, 22 (86), 111-124.

Fortunella, A. P., dan Hadiprajitno, B. (2015). The effects of corporate governance structure and firm characteristic towards environmental disclosure. Diponegoro Journal of Accounting, 4 (2), 1-11, issn: 2337-3806.

Haniffa, R.M. dan Cooke, T.E. (2005). The impact of culture and governance on corporate social reporting. Journal of Accounting and Public Policy, 24, 391-430.

Ho, Simon S.M dan Wong, K. (2001). A study of the relationship between corporate governance structures and the extent of voluntary disclosure. Journal of International Accounting Auditing And Taxatiiion, 10 (2), 139-156.

Hogg, M. A., dan Vaughan, G. M. (2008). Social Psychology. Edition 5. London : Pearson Education Limited.

Isaksson, R., and U.Steimle. (2009). What does GRI reporting tell us about corporate sustainability?. The TQM Journal, 21 (2), 168-181.

Kartadjumena, E., Dudi, A. Hadi. dan Novan, B. (2011). The relationship of profit and corporate social responsibility disclosure (survey on manufacture industry in Indonesia). 2nd International Conference on Business and Economic Research, Proceeding.

Katmon, N., Mohamad, Z. Z., Norwani, N. M., dan Al Farooque, O. (2017). Comprehensive board diversity and quality of corporate social responsibility disclosure: evidence from an emerging market. Journal of Business Ethics, 1-35.

Khan, A., Muttakin, M. D. dan Siddiqui, J. (2013). Corporate governance and corporate social responsibility disclosure: evidence from an emerging economy. Journal Bussines Ethics, 114, 207-223.

Kharis, A., dan Suhardjanto, D. (2012). Corporate governance dan ketaatan pada badan umum milik negara. Jurnal Keuangan dan Perbankan, 16, 37-44.

Komite Nasional Kebijakan Governance (KNKG). (2011). Pedoman Umum Good Corporate Governance Indonesia. Jakarta. 
Komite Nasional Kebijakan Governance (KNKG). (2006). Pedoman Umum Good Corporate Governance Indonesia. Jakarta.

Kusumastuti, S., Supatmi, dan Perdana S. (2007). Pengaruh board diversity terhadap nilai perusahaan dalam perspektif corporate governance. Jurnal Akuntansi Dan Keuangan, 9 (2), 88-98.

Liao, L., Luo, L., dan Tang, Q. (2015). Gender diversity, board independence, environmental committee and greenhouse gas disclosure. The British Accounting Review, 47 (4), 409-424.

Lie, J., R., Pike, dan R., Haniffa. (2008). Intellectual capital disclosure and corporate governance structure in UK firms. Accounting and Business Research, 38 (2), 137-159.

Luckerath-Rovers, M. (2011). Women on boards and firm performance. Journal of Management \& Governance, 17(2), 492-509.

Lukviarman, N. (2016). Corporate Governance. PT Era Adicitra Intermedia : Solo.

Mc Mullen, D.A. (1996). Audit committee performance: an investigation of the consequences associated with audit committee. Auditing: A Journal of Theory and Practice, 15 (1), 87-103.

Muntoro, R. K. (2005). Membangun Dewan Komisaris yang Efektif. Majalah Usahawan Indonesia No.11 Tahun XXXVI, 15 Januari, 15.

Pratama, Agny Gallus, dan Rahardja. (2013). Pengaruh good corporate governance dan kinerja lingkungan terhadap pengungkapan lingkungan (studi empiris pada perusahaan manufaktur dan tambang yang terdaftar pada BEI dan termasuk dalam PROPER tahun 2009-2011). Diponegoro Journal of Accounting, 2 (3), 114.

Rahmawati, M. I. dan Subardjo, A. (2017). Pengaruh pengungkapan lingkungan dan kinerja lingkungan terhadap kinerja ekonomi yang dimoderasi good corporate governance. Jurnal Buletin Studi Ekonomi, 22 (2).

Republik Indonesia. (2012). Peraturan Pemerintah No. 47 tentang Tanggung Jawab Lingkungan dan Sosia Perseroan Terbatas.

Rokhimatika, A., dan Afandy, C (2017). Analisis Tingkat Kesehatan Bank dengan Menggunakan Metode Risk Profile, Good Corporate Governance, Earning, Capital (RGEC). Managament Insight: Jurnal IImiah Manajemen. 12(1), 12-27

Said, R., Y. Hj Zainuddin, dan H. Haron. (2009). The relationship between corporate governance characteristics in Malaysian public listed companies. Social Responsibility Journal, 5 (2), 212-226.

Santrock, J. W. (2006). Human Adjustment. New York : Mc Graw-Hill.

Setyawan, H. dan Kamilla, P. (2015). Impact of corporate governance on corporate environmental disclosure: Indonesian evidence. Proceeding ICTEHM $15^{\text {th }}$. Pattaya, Thailand.

Setyawan, S. 2005. Konteks budaya etnis tionghoa dalam manajemen sumber daya manusia. Jurnal Manajemen dan Bisnis BENEFIT, 9 (2), 164-170. 
Sufian, M. A. dan Zahan, M. (2013). Owner structure and corporate social responbility disclosure in Bangladesh. International Journal Economics and Financial, 3 (4).

Sugiyono. 2007. Menjawab Stigma, Mewariskan Tradisi. http://www.kabarejogja.com/new/canthing2.html. Diakses pada 10 desember 2017.

Suhardjanto, D. (2010). Corporate governance, karakteristik perusahaan dan environmental disclosure. Prestasi, 6 (1), ISSN 1411-1497.

Suhardjanto, D., Tower, G., dan Brown, A.M. (2008). Indonesian stakeholders' perceptions on environmental information. Journal of the Asia-Pacific Centre for Environmental Accountability, 14 (4), 2-11.

Suhardjanto, D. dan Permatasari, D. N. (2010). Pengaruh corporate governance, etnis, dan latar belakang pendidikan terhadap environmental reporting index. Kinerja, 14 (1), 151-164.

Suhardjanto, D. \& Anggitarani, A. (2010). Karakteristik dewan komisaris dan komite audit serta pengaruhnya terhadap kinerja keuangan perusahaan. Jurnal Akuntansi, 2: 125-245.

Sulistyowati. (2014). Pengaruh corporate governance terhadap environmental disclosure (studi empiris pada perusahaan manufaktur dan pertambangan yang listing di bei tahun 2010-2012). Artikel Mahasiswa, Fakultas Ekonomi, UNEJ.

Supatminingsih, S. dan Wicaksono, M. (2016). Pengaruh corporate governance terhadap pengungkapan lingkungan perusahaan bersertifikasi iso $14001 \mathrm{di}$ Indonesia. Jurnal Akuntansi dan Pajak, 17 (1).

Suratno, Darsono, dan Siti Mutmainah. (2006). Pengaruh environmental performance terhadap environmental disclosure dan economic performance: studi empiris pada perusahaan manufaktur yang terdaftar di bursa efek jakarta periode 2001-2004. SNA IX Padang.

Suwardjono. 2010. Teori Akuntansi: Pengungkapan dan Sarana Interpretatif. Edisi Ketiga. BPFE, Yogyakarta.

Suryono, H. dan A. Prastiwi. (2011). Pengaruh karakteristik perusahaan dan corporate governance terhadap praktik pengungkapan sustainability report. SNA XIV Aceh.

Visser. W. (2008). The New Era of Sustainability and Responsbility. CSR International Inspiration Series, No. 1.

WALHI. (2017). Available at: https://daerah.sindonews.com/read/1193865/21/miris30-pabrik-di-dayeuhkolot-buang-limbah-ke-sungai-1491212988. Diakses tanggal 10 juni 2017

WALHI. (2018). Available at: https://www.walhi.or.id/tinjauan-lingkungan-hidup-2018. Diakses tanggal 4 oktober 2018. 